\section{A PCR Method to Detect Myxobolus acanthogobii (Myxozoa: Myxosporea), the Causative Agent of Skeletal Deformities of Marine Fishes}

\author{
Seiji Miyajima ${ }^{1}$, Hiroshi Yokoyama ${ }^{1 *}$ \\ Yutaka Fukuda $^{2}$, Kumiko Okamoto ${ }^{2}$ \\ and Kazuo Ogawa ${ }^{1}$
}

\author{
${ }^{1}$ Department of Aquatic Bioscience, Graduate School of \\ Agricultural and Life Sciences, The University of Tokyo, \\ Tokyo 113-8657, Japan \\ ${ }^{2}$ Fisheries Research Institute, Oita Prefectural Agriculture, \\ Forestry and Fisheries Research Center, \\ Oita 879-2602, Japan
}

(Received August 22, 2005)

\begin{abstract}
A polymerase chain reaction (PCR) method was developed to detect Myxobolus acanthogobii, a myxozoan parasite causing skeletal deformities in marine fishes. The PCR system targeting SSU rDNA of $M$. acanthogobii was confirmed to be species-specific; the detection limits of a single- and a nested-PCR were 1 and $0.01 \mathrm{pg}$ DNA, respectively. Nested-PCR analyses were applied to epizootiological surveys of $M$. acanthogobii in cultured Japanese mackerel Scomber japonicus and in feral fishes (37 species). Three wild fishes, forksnout searobin Lepidotrigla alata, crimson seabream Evynnis japonica and scribbled toby Canthigaster rivulata, were found to be the hosts for M. acanthogobii.
\end{abstract}

Key words: Myxobolus acanthogobii, diagnosis, PCR, skeletal deformity

Myxobolus buri, the aetiological agent of the myxosporean scoliosis in cultured yellowtail Seriola quinqueradiata $^{1}$, was recently synonymized with $M$. acanthogobif), which was described from the brain of yellowfin goby Acanthogobius flavimanus ${ }^{3)}$. More recently, the parasite has been found to be responsible for a skeletal deformity of cultured Japanese mackerel Scomber japonicus ${ }^{4}$. Conventional diagnoses have been based on microscopic observation of tissue imprints of the brain. The sensitivity of this method is generally low because only spore stages can be detected. Previously, a PCR method for detection of $M$.

\footnotetext{
* Corresponding author

E-mail: ayokoh@mail.ecc.u-tokyo.ac.jp
}

acanthogobii was developed by Yokoyama et al. ${ }^{2)}$. However, non-specific reactions to fish DNA were occasionally found, suggesting that the PCR had a risk of false positive results (Miyajima et al., unpublished data). Consequently, improvement of PCR method is required to detect $M$. acanthogobii in higher sensitivity and specificity.

\section{Materials and Methods}

The primers Ma-fwd1, Ma-fwd3 and Ma-rev4 were newly designed from the SSU rDNA sequence of $M$. acanthogobii (GenBank accession no. AY541585) (Table 1). In the first PCR, the primers Ma-fwd1 and Ma-rev ${ }^{2)}$ were employed to amplify a $727 \mathrm{bp}$ fragment. In the second PCR, the primers Ma-fwd3 and Ma-rev4 were employed to amplify a $671 \mathrm{bp}$ fragment. Before PCR, the brain tissue was homogenized, if required, and digested in TNES-urea buffer with proteinase $\mathrm{K}$ overnight at $37^{\circ} \mathrm{C}$. DNA was purified by standard phenol/chloroform/isoamyl alcohol and diethyl ether extraction and ethanol precipitation. The precipitated DNA was resuspended in sterilized $\mathrm{H}_{2} \mathrm{O}$ and DNA concentration was adjusted to $<200 \mathrm{ng} / \mu \mathrm{L}$ following the manufacturer's instructions (Takara, Kyoto, Japan). In the first PCR, each PCR mixture contained $3.7 \mu \mathrm{L}$ Taq solution (Takara) (mix containing TaKaRa Ex Taq ${ }^{\mathrm{TM}} \mathrm{HS}(5 \mathrm{U} / \mu \mathrm{L})$, $10 \times$ Ex Taq Buffer (including $20 \mathrm{mM} \mathrm{Mg}^{2+}$ ) and dNTP Mixture (2.5 mM each) in the ratio 1:20:16), $0.6 \mu \mathrm{L}$ of each primer ( $25 \mathrm{pmol} / \mu \mathrm{L}), 1 \mu \mathrm{L}$ of DNA sample and sterilized $\mathrm{H}_{2} \mathrm{O}$ to a final volume of $20 \mu \mathrm{L}$. The cycling conditions were 30 cycles of denaturation $\left(95^{\circ} \mathrm{C}\right.$ for $\left.30 \mathrm{~s}\right)$, annealing $\left(64^{\circ} \mathrm{C}\right.$ for $\left.30 \mathrm{~s}\right)$ and extension $\left(72^{\circ} \mathrm{C}\right.$ for $\left.30 \mathrm{~s}\right)$, which were preceded by an initial $4 \mathrm{~min}$ denaturation step at $95^{\circ} \mathrm{C}$ and followed by a final 7 min extension at $72^{\circ} \mathrm{C}$. In the second PCR, each PCR mixture contained $1.8 \mu \mathrm{L}$ Taq solution, $0.3 \mu \mathrm{L}$ of each primer $(25 \mathrm{pmol} / \mu \mathrm{L})$, $1 \mu \mathrm{L}$ of the product from the first amplification and sterilized $\mathrm{H}_{2} \mathrm{O}$ to a final volume of $20 \mu \mathrm{L}$. The cycling conditions were the same as the first PCR except only 15 cycles were performed and annealing was at $60^{\circ} \mathrm{C}$. Taq polymerase was kept on ice until the preheating step. PCR products were electrophoresed on an agarose gel with ethidium bromide and visualized under UV transillumination.

To assess the sensitivity of this PCR method, a suspension of parasite spores was purified from the brain

Table 1. Primer sequences used for the present study

\begin{tabular}{lc}
\hline Primer & \multicolumn{1}{c}{ Sequence } \\
\hline Forward & \\
Ma-fwd1 & 5'- TAC AAC ACG CTG CGC TGT AG -3' \\
Ma-fwd3 & 5'- GCC ATG CAT GTG AGT AGT AC -3' \\
Reverse & \\
Ma-rev4 & 5'- GAT CCG AAT CTT TGG CAC CA -3' \\
Ma-rev & 5'- CCA CAC AGA CTC CAC TGCA -3' \\
\hline
\end{tabular}


surfaces of yellowfin gobies. The DNA concentration was checked and serial dilutions of spore samples (10 to $10^{-3} \mathrm{pg} \mathrm{DNA} / \mu \mathrm{L}$ ) were prepared in duplicate. Initial DNA concentrations of spore samples were adjusted to $10^{2} \mathrm{ng} / \mu \mathrm{L}$ by adding DNA of Japanese mackerel. The DNA of Japanese mackerel only $\left(10^{2} \mathrm{ng} / \mu \mathrm{L}\right)$ and sterilized $\mathrm{H}_{2} \mathrm{O}$ were used as negative controls and the DNA of the spore suspension only $(10 \mathrm{ng} / \mu \mathrm{L})$ was used as a positive control. The specificity of the single- and the nested-PCR methods was evaluated with eight other myxosporean species (Trigonosporus acanthogobii, Henneguya tridentigeri, Myxobolus episquamalis, $M$. artus, M. arcticus, Enteromyxum fugu, Kudoa amamiensis and $K$. shiomitsui). DNAs of these myxosporeans were extracted using the above method or DNeasy Tissue Kit (Qiagen Inc., Germany).

Epizootiological surveys of $M$. acanthogobii in cul-

Table 2. Fish species examined in the epizootiological survey performed near the fish farm of Japanese mackerel Scomber japonicus in Oita Prefecture. The skeletal deformity caused by Myxobolus acanthogobii was enzootic in this farm.

\begin{tabular}{|c|c|c|}
\hline Order & Scientific name & alence \\
\hline Anguilliformes & Anago anago & $0 / 1^{*}$ \\
\hline Aulopiformes & Saurida spp. & $0 / 25$ \\
\hline \multirow[t]{2}{*}{ Lophiiformes } & Autennarius striatus & $0 / 1$ \\
\hline & Lophiomus setigerus & $0 / 5$ \\
\hline \multirow[t]{17}{*}{ Perciformes } & Amblychaeturichthys hexanema & $0 / 5$ \\
\hline & Apogon semilineatus & $0 / 31$ \\
\hline & Branchiostegus japonicus & $0 / 1$ \\
\hline & Evynnis japonica & $1 / 24$ \\
\hline & Kaiwarinus equula & $0 / 7$ \\
\hline & Leiognathus rivulatus & $0 / 39$ \\
\hline & Pagrus major & $0 / 2$ \\
\hline & Parapercis sexfasciata & $0 / 10$ \\
\hline & Parapristipoma trilineatum & $0 / 1$ \\
\hline & Plectorhinchus cinctus & $0 / 1$ \\
\hline & Scomber australasicus & $0 / 9$ \\
\hline & Scomber japonicus & $0 / 1$ \\
\hline & Scombrops boops & $0 / 1$ \\
\hline & Sphyraena pinguis & $0 / 1$ \\
\hline & Trachurus japonicus & $0 / 5$ \\
\hline & Upeneus bensasi & $0 / 2$ \\
\hline & Uranoscopus japonicus & $0 / 4$ \\
\hline \multirow[t]{3}{*}{ Pleuronectiformes } & Pseudaesopia japonica & $0 / 4$ \\
\hline & Pseudorhombus pentophthalmus & $0 / 10$ \\
\hline & Samaris cristatus & $0 / 1$ \\
\hline \multirow[t]{8}{*}{ Scorpaeniformes } & Bembradium roseum & $0 / 2$ \\
\hline & Lepidotrigla alata & $1 / 77$ \\
\hline & Lepidotrigla japonica & $0 / 10$ \\
\hline & Lepidotrigla microptera & $0 / 2$ \\
\hline & Onigocia spinosa & $0 / 8$ \\
\hline & Scorpaena miostoma & $0 / 8$ \\
\hline & Scorpaenopsis neglecta & $0 / 1$ \\
\hline & Suggrundus meerdervoorti & $0 / 2$ \\
\hline \multirow[t]{2}{*}{ Syngnathiformes } & Fistularia commersonii & $0 / 1$ \\
\hline & Hippocampus takakurai & $0 / 1$ \\
\hline \multirow{3}{*}{ Tetraodontiformes } & Canthigaster rivulata & $0 / 1$ \\
\hline & Stephanolepis cirrhifer & $0 / 9$ \\
\hline & Thamnaconus modestus & $0 / 1$ \\
\hline
\end{tabular}

* The number of fish infected/the number of fish examined. tured Japanese mackerel at Oita Prefecture were carried out. Brains of a total of 200 fish from a fish farm which had a history of the myxosporean infection and 100 fish from the Fisheries Research Institute (FRI) of Oita Prefecture, which had no previous history of the disease, were examined by the nested-PCR method and microscopic observations of the brain imprints almost monthly from June 2004 to March 2005 . Field surveys were performed on a total of 314 individuals in 37 species (Table 2) of feral fishes collected in the vicinity of the fish farm on four occasions (June 2004, November 2004, March 2005, and May 2005). When M. acanthogobii was detected by PCR, the brain homogenate in TNES-urea buffer was checked for a presence of spores by microscopy. In addition, PCRs and morphological observations were carried out with a myxosporean found in yellowish-white cysts on the surface of the brain and in the spinal cord of scribbled toby Canthigaster rivulata collected at Aburatsubo bay, Kanagawa Prefecture.

\section{Results and Discussion}

Detection thresholds of the single- and the nestedPCR tests were 1 and $0.01 \mathrm{pg}$ DNA (equivalent to ca. 0.001 spores), respectively (Fig. 1). Amplification was not observed for the eight other myxosporeans by either the single- or the nested-PCR (Fig. 2). The present study demonstrates that the PCR method has a high sensitivity and specificity for the detection of $M$. acanthogobii. However, in a practical sense, even the single-PCR may be sufficient for routine diagnoses because all fishes found positive by the nested-PCR were also positive by the single-PCR. Nevertheless, the nested-PCR would be useful for detection of early presporogonic stages of $M$. acanthogobii.

Among the cultured Japanese mackerel, only one out of 30 fish was found positive in September 2004 for $M$. acanthogobii infection by the nested-PCR. Although the fish was negative in the brain imprint, $M$. acanthogobii spores were subsequently found in the brain homogenate using light microscopy. These results indicate that the PCR method is more sensitive than the brain imprint method. All fish from the FRI appeared negative. No PCR amplification was obtained with Kudoa sp. which was incidentally found in the brain of Japanese mackerel (data not shown). Compared with the previous results by Yokoyama et al.," which shows that the prevalence of infection of $M$. acanthogobii in over-wintered Japanese mackerel at the same farm was $12.5 \%$ from May to October 2003, the current survey found extremely low prevalence (only one out of 200 fish). The reason for the decrease in prevalence is unknown, and further long-term surveys are required.

By the nested-PCR tests, one of 26 forksnout searobin Lepidotrigla alata and one of 24 crimson seabream Evynnis japonica collected in November 2004 


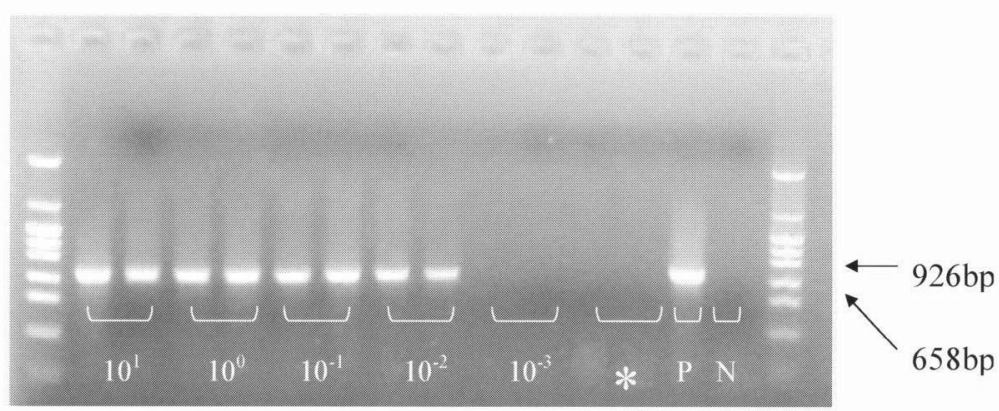

Fig. 1. Assessment for sensitivity of the nested-PCR method for the detection of Myxobolus acanthogobii (pg DNA / $20 \mu \mathrm{L}-\mathrm{PCR}$ tube). Lane *, DNA of Japanese mackerel Scomber japonicus; Lane P, positive control; Lane N, negative control (sterilized $\mathrm{H}_{2} \mathrm{O}$ ).

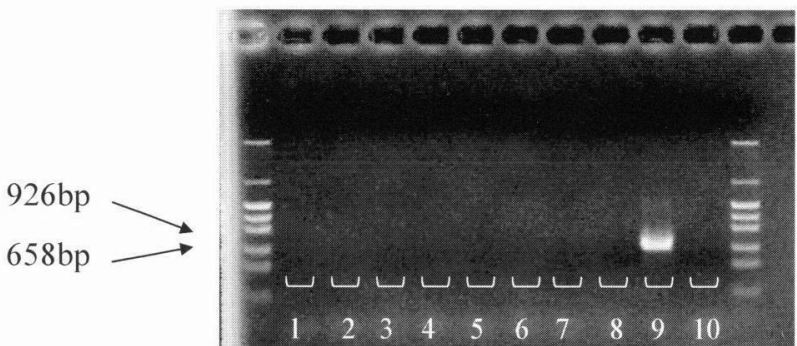

Fig. 2. Assessment for specificity of the nested-PCR method for the detection of Myxobolus acanthogobii. DNAs of (1) Trigonosporus acanthogobii, (2) Henneguya tridentigeri, (3) Myxobolus episquamalis, (4) M. artus, (5) M. arcticus, (6) Enteromyxum fugu, (7) Kudoa amamiensis, (8) K. shiomitsui. Lane9, positive control; Lane10, negative control (sterilized $\mathrm{H}_{2} \mathrm{O}$ ).

were positive for $M$. acanthogobii, although the fishes did not show any skeletal abnormalities. Spores were also found in the brain imprint and the homogenate of the forksnout searobin. The morphological characteristics of the spores found in the homogenate were consistent with those of $M$. acanthogobii.

DNA of the myxosporean found from a scribbled toby was successfully amplified by PCR. Spore morphology and dimensions also supported that the parasite was identified as $M$. acanthogobii. An unidentified Myxobolus parasite was described from the cerebro-spinal system of scribbled toby collected at Misaki, Kanagawa Prefecture, by Okada ${ }^{5}$. Taking into consideration the morphological features, the host species, the site of infection and the locality, it is reasonable enough to conclude that this unidentified parasite was $M$. acanthogobii.

Our study confirms that the host range of $M$. acanthogobii is very broad. M. acanthogobii has been known to parasitize $A$. flavimanus, $S$. quinqueradiata, $S$. japonicus, Scombrops boops, Chelidonichthys spinosus and $C$. rivulata ${ }^{1,3,4,6)}$. This study adds two hosts, $L$. alata and $E$. japonica, to the list, though it remains to be clarified whether these hosts exhibit skeletal deformities or not. In the current environment of diversification in mariculture finfish species, there is real significant risk of spreading infections of $M$. acanthogobii to other cultured fishes because of its broad host range. The present PCR method will be useful for detection of $M$. acanthogobii.

\section{Acknowledgements}

We are thankful to Dr. Kathryn A. Hall, the University of Tokyo, for reviewing this manuscript. This study was partly supported by the Grant-in-Aid for Scientific Research (C) from Japan Society for the Promotion of Science (No. 17580157).

\section{References}

1) Egusa, S. (1985): Fish Pathol., 19, 239-244. 2) Yokoyama, H., M. A. Freeman, T. Yoshinaga and K. Ogawa (2004): Fish. Sci., 70, 1036-1042. 3) Hoshina, T. (1952): J. Tokyo Univ. Fish., 39, 69-89. 4) Yokoyama, H., M. A. Freeman, N. Itoh and Y. Fukuda (2005): Dis. Aquat. Org., 66, 1-7. 5) Okada, Y. K. (1932): Bull. Soc. Zool. France, 57, 39-44. 6) Maeno, Y. and S. Sorimachi (1992): NOAA Tech. Rep. NMFS, 111, 113118. 